\title{
Poster number AD-1340 Efficacy of glimepiride as an add-on therapy to insulin in patients with high insulin requirement
}

\author{
Dr Jayant Kelwade, Dr Bipin Sethi \\ CARE Hospital, Hyderabad, India
}

\begin{abstract}
Introduction :
Insulin therapy is needed for achieving glycemic control in many patients of type 2 diabetes after they fail to respond to oral antidiabetic drugs (OADs). However many patients do not achieve the glycemic goal despite intensification of insulin therapy. Questions have been repeatedly raised concerning the role of hyperinsulinemia in the pathogenesis of diabetic complications (Weight gain, increased risk of atherosclerosis, development of proliferative retinopathy etc.).In this context, an orally administered drug that could simplify the patient's insulin regimen and achieve similar results would be a welcome adjunct. In these instances, in most patients metformin is usually continued along with insulin. But metformin may be contraindicated or not well tolerated in some patients. Glitazones and/or DPP-4 inhibitors can be added, the former has the propensity to produce edema and the latter is expensive.

Glimepiride, a second generation SU (sulphonylureas), has both pancreatic and extra-pancreatic actions. Through pancreatic action it increases insulin secretion while its extra-pancreatic action causes increase insulin sensitivity, glucose uptake and decrease gluconeogenesis. Addition of SUs to current insulin therapy helps in improving glycemic control and reduces the doses of insulin required. Further it offers advantages of overall cost reduction. Combination of insulin and glimepiride has undergone limited assessment and needs to be explored in a resource limited world.
\end{abstract}

\section{Aims and Objectives}

1. To determine the efficacy of Glimepiride as an add- on therapy to Insulin, in patients requiring more than 1 unit per kilogram per day of Insulin

2. To determine improvement in B cell function, manifested by an increase in c-peptide level in patients on add- on therapy with Glimepiride compared to patients who have not been started on add- on therapy with Glimepiride.

\section{End points}

Primary: Change from baseline in $\mathrm{HbA} 1 \mathrm{c}$ after 6 months of randomized treatment

Secondary: 1. Mean dose reduction of Insulin (dosage from baseline at end of the study)

2.. Safety and tolerability

\section{Matrials and Methods}

Study site: CARE OUTPATIENT CLINIC, BANJARA HILLS, HYDERABAD

Subjects: Patient of type 2 Diabetes Mellitus on Insulin $>$ one unit per kilogram of body weight ( $>1$ units $/ \mathrm{kg}$ of body weight)

Study design:A prospective randomized comparative study.

Sample size: Group A- 24(Insulin + Metformin + Glimepiride)

Study duration: 6 months

Group B- 24(Insulin + Metformin)

Both the groups were comparable to baseline characteristic. Average duration of diabetes in group $A$ was $15.7 \pm 4$ years and that in group B was $15.5 \pm 2.3$ years.

\section{Results and Discussion}

In our study, both groups showed significant reduction in FPG, PPPG and HbA1c from baseline. However, at the end of 24 weeks Group A showed statistically significant reduction in FPG $(110.5 \pm 13 \mathrm{mg} / \mathrm{dl}$ vs $125.4 \pm 20.9 \mathrm{mg} / \mathrm{dl}$, p-value 0.005), PPPG $(158.2 \pm 11.8 \mathrm{mg} / \mathrm{dl}$ vs $\quad 171.7 \pm 23.2 \mathrm{mg} / \mathrm{dl}, \mathrm{p}=0.01)$ and $\mathrm{HbA} 1 \mathrm{c}(1.7 \%$ vs $1.1 \%)$ compared to group B. Addition of glimepiride to insulin causes significant reduction in insulin requirement $(95.7 \pm 28.5$ units/day in group A vs $135.9 \pm 29.6$ units/day in group $B, p<0.0001)$. The required insulin doses were reduced by $4.01 \%$ (from $99.7 \pm 17.1$ to $95.7 \pm 28.5$ units /day) in the group $A$, while it was increased by $38.27 \%$ (from $98.3 \pm 17.9$ to $135.9 \pm 29.6$ units /day) in the group $B$, the difference in two groups was statistically significant. Surprisingly in our study, the numbers of hypoglycemic episodes were very less in subjects treated with combined insulin and glimepiride as compared to the subjects treated with insulin alone (11 vs 23 ). Also $58 \%$ of the subjects treated with increasing insulin doses experienced at least one episode of hypoglycaemia, while only $29 \%$ of the subjects with glimepiride added group experienced at least one episode of hypoglycaemia. Serum c- peptide concentration increased significantly in insulin and glimepiride treated group $(0.82 \pm 0.34$ vs $1.01 \pm 0.23, p$ - value 0.02$)$ in contrast to decrease in c-peptide concentration in subjects treated with insulin alone $(0.82 \pm 0.2$ vs $0.78 \pm 0.34, p=0.63)$. Weight gain was observed in both the group. In sub analysis of group $A$ patients, those with higher $\mathrm{HbA1c}$ and low c-peptide level responded poorly to treatment.

\begin{tabular}{|c|c|c|c|c|c|c|c|}
\hline & \multicolumn{2}{|c|}{$\begin{array}{c}\text { Group A } \\
(\mathrm{N}=24)\end{array}$} & \multicolumn{2}{|c|}{$\begin{array}{c}\text { Group B } \\
(\mathrm{N}=24)\end{array}$} & \multirow[b]{2}{*}{$\begin{array}{c}\text { P value } \\
\text { Gr A } \\
\text { Vs } \\
\text { Gr B }\end{array}$} & \multirow[b]{2}{*}{$\begin{array}{l}\text { P value } \\
\text { Gr A } \\
\text { (0 vs } 24 \\
\text { wks) }\end{array}$} & \multirow[b]{2}{*}{$\begin{array}{l}\text { P value } \\
\text { Gr B } \\
\text { (0 vs } 24 \\
\text { wks) }\end{array}$} \\
\hline & 0 wks & 24 wks & 0 wks & 24 wks & & & \\
\hline $\begin{array}{l}\text { Wt } \\
(\mathrm{kg})\end{array}$ & $77.2 \pm 8.6$ & $78.2 \pm 8.4$ & $76.7 \pm 8.2$ & $\begin{array}{c}79.5 \pm \\
10.2\end{array}$ & 0.63 & $0.0001 *$ & $0.003 *$ \\
\hline FPG & $\begin{array}{c}154.8 \pm \\
24.6\end{array}$ & $\begin{array}{c}110.5 \pm \\
13\end{array}$ & $\begin{array}{c}155.3 \pm \\
36.2\end{array}$ & $\begin{array}{l}125.4 \\
\pm 20.9\end{array}$ & $0.005^{*}$ & $0.0001 *$ & $0.0001 *$ \\
\hline PPPG & $\begin{array}{c}231.1 \pm \\
41.4\end{array}$ & $\begin{array}{c}158.2 \pm \\
11.8\end{array}$ & $\begin{array}{c}231.2 \pm \\
36.3\end{array}$ & $\begin{array}{c}171.7 \pm \\
23.2\end{array}$ & $0.01 *$ & $0.0001 *$ & $0.0001 *$ \\
\hline $\mathrm{HbA} 1 \mathrm{c}$ & $9.1 \pm 1.4$ & $7.4 \pm 0.5$ & $9.1 \pm 0.9$ & $8.0 \pm 0.76$ & $0.002 *$ & $0.0001 *$ & $0.0001 *$ \\
\hline $\begin{array}{l}\text { Insulin } \\
\text { doses }\end{array}$ & $\begin{array}{c}99.7 \pm \\
17.1\end{array}$ & $\begin{array}{c}95.7 \pm \\
28.5\end{array}$ & $\begin{array}{c}98.3 \pm \\
17.9\end{array}$ & $\begin{array}{c}135.9 \pm \\
29.6\end{array}$ & $0.0001^{*}$ & 0.15 & $0.0001 *$ \\
\hline $\begin{array}{l}\text { C- } \\
\text { peptide }\end{array}$ & $0.82 \pm 0.34$ & $1.01 \pm 0.23$ & $0.82 \pm 0.2$ & $0.78 \pm 0.34$ & $0.009^{*}$ & $0.02 *$ & 0.63 \\
\hline
\end{tabular}

$\underline{\text { Conclusions }}$

1. Addition of glimepiride to insulin treated patient led to better glycemic control with significant decrease in requirement of insulin dose.

2. Glimepiride when added to insulin is well tolerated and associated with significantly lesser risk of hypoglycemia as compared to patients treated with insulin alone.

3. Although weight gain was observed in insulin and glimepiride treated group, it is numerically lesser than that of patients treated with insulin alone.

4. Patients with low c-peptide and very high $\mathrm{HbA1c}$ level with longer duration of diabetes may not respond to addition of glimepiride. 